\title{
Effects of Coal Bottom Ash as Cementitious Material on Compressive Strength and Chloride Permeability of Concrete
}

\author{
Mohd Haziman Wan Ibrahim ${ }^{1 *}$, Sajjad Ali Mangi ${ }^{2}$, Mohd Irwan Juki ${ }^{1}$ \\ ${ }^{1}$ Jamilus Research Center, Faculty of Civil and Environmental Engineering, \\ Universiti Tun Hussein Onn Malaysia, Parit Raja, 86400, Johor, MALAYSIA \\ ${ }^{2}$ Department of Civil Engineering, \\ Mehran University of Engineering and Technology, SZAB Campus, Khairpur Mir's, 66020, Sindh, PAKISTAN
}

DOI: https://doi.org/10.30880/ijscet.2020.11.02.001

Received 30 July 2020; Accepted 30 August 2020; Available online 02 September 2020

\begin{abstract}
Coal Bottom Ash (CBA) is the waste material produced by coal-based power plants, particularly in Malaysia around 1.7 million tons of CBA was produced annually, which is major environmental concern. Therefore, the use of CBA as a partial replacement of cement in concrete is a possible solution for that pollution; this approach also creates a new corridor in the field of concrete production. However, this study aims to evaluate the effects of CBA as cementitious material on the concrete properties. This study incorporated $10 \%$ CBA as a cement replacement by weight method in concrete. However, concrete samples were prepared with and without CBA and immersed in water for 7, 28, 56 and 90 days. Next, the performances of concrete with and without CBA were evaluated in terms of workability, compressive strength, and rapid chloride permeability test. It was found that due to presence of CBA in concrete, workability reduces; no substantial growth in compressive strength at the early ages but substantial rise in strength was noticed after 56 days. Almost $4.7 \%$ higher strength was recorded than the control specimens at 90 days. Besides that, concrete containing CBA has lower chloride penetration as compared to the control specimen, which shows its better durability performance. It can be concluded that CBA has an enormous potential to be utilized as a cementitious material in durable concrete production.
\end{abstract}

Keywords: Coal bottom ash, cement replacement, concrete, compressive strength, chloride permeability.

\section{Introduction}

The concrete consumption is increased due to worldwide infrastructure development and it is predicted that it will reach to $18 \times 10^{9}$ tons by 2050 (Rafieizonooz, et al., 2016). Due to rise in the concrete consumption, the demand of Ordinary Portland Cement (OPC) is increased gradually, which causes high production of corban dioxide $\left(\mathrm{CO}_{2}\right)$ and leads to environmental pollution (Aydin, 2016) (Mangi et al., 2017). Therefore, it is necessary to introduce such materials that could reduce the practice of OPC, it could be a possible alternative for the reduction in $\mathrm{CO}_{2}$ emissions produced through OPC manufacturing. Beside that it was stated by Sathonsaowaphak, Chindaprasirt, \& Pimraksa, (Sathonsaowaphak et al., 2009) that the coal based power station waste has a substantial potential to be considered as cementitious material. The burning of coal for the purpose of power generation, results in the generation of noncombustible ashes like coal bottom ash (CBA) and fly ash (FA) as shown in Fig.1.

It is worldwide estimated that annual coal ash generation is around 600-800 million tons (Hui, et al., 2009). Coal ash that is removed from the flue gases in an electro-precipitator is named as fly ash (FA) which is around 70-80\% of total ash and remaining 20-30\% of heavyweight ash falls at the lower part of the furnace, which is known as coal bottom ash (CBA) (Singh, et al., 2015). Moreover, Rafieizonooz, et al., (2016) stated that the CBA is a waste of power plant 
which is being disposed-off in to the open ponds which occupies huge area of land countrywide and simultaneously creates environmental pollution.

In America, the coal-fired power plants produces around $22.6 \times 10^{6}$ tons of fly ash and $3.8 \times 10^{6}$ tons of CBA (ACAA, 2017). Particularly in Malaysia, about $6.8 \times 10^{6}$ tons of fly ash and roughly $1.7 \times 10^{6}$ tons of CBA is being produced, and in Indian about 155 power plants are operated on coal and produces approximately $169.25 \times 10^{6}$ tons of fly ash (FA) and $34 \times 10^{6}$ tons of CBA (CEA, 2017).

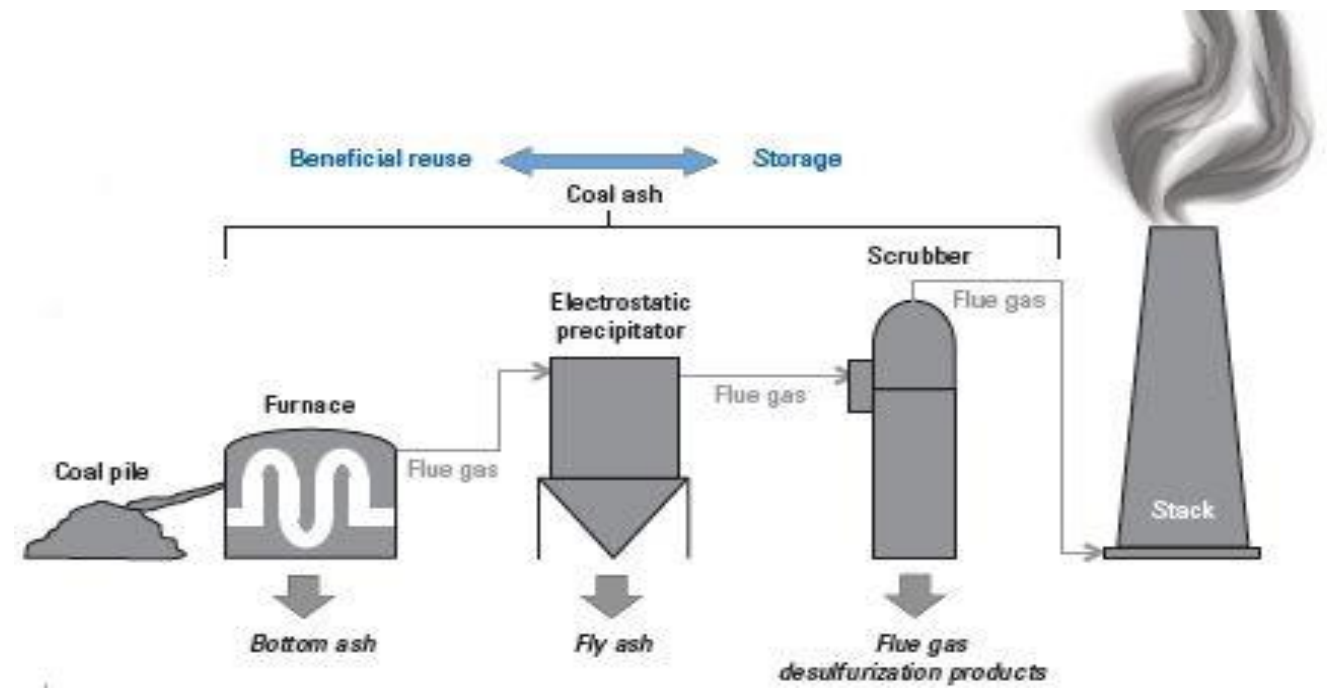

Fig. 1 - Processes flow of coal combustion and generation of coal ashes at coal-fired powerplant (Deonarine, Kolker, \& Doughten, 2015)

However, the safe handling of CBA is still a challenge for the consumers, therefore engineers are looking for the possible solution to utilize it in the field of construction engineering. Although it was previously declared as pozzolanic material and encouraged to practice as partially replace with OPC (Cheriaf, Rocha, \& Pera, 1999). However, the pozzolanic property of the CBA is directly related to its particle fineness (Kim, 2015), which confirms that grinding process is essential to make it useable as a cementitious material. The application of CBA as a cementitious material has received very limited as it requires grinding process. In review of recent research, possibility of use of CBA in concrete as a sand or cement replacement has been previously conducted by various researchers as mentioned below.

Kadam \& Patil, (2014), they used sieved CBA as 70\% sand replacement and with an addition of cement 5 to $30 \%$. The results demonstrated that compressive strength of concrete containing sieved CBA with extra cement were lower than the control mix at 7 to 112 days.

Rafieizonooz et al., (2016), considered fly ash as replacement of cement (20\%) and CBA as replacement of sand with 25 to $100 \%$ in concrete with fixed w/c ratio of 0.55 . The strength was reduced at the early days but at the age of 91 days, concrete compressive strength with CBA was reached to results of control mix specimens. Moreover, at the age of 91 and 180 days, the establishment of additional C-S-H gel due to portlandite consumption by pozzolanic action of CBA and fly ash shows higher compressive strength as compared to control mix.

Singh \& Siddique (2016) replaced the sand with CBA from 20 to $100 \%$ in concrete and results demonstrated that concrete containing sand with 2.58 fineness modulus, when replaced with CBA, tensile and compressive strength was reduced at early curing days but later 90 days, it was comparable to that of control mix concrete. Since they suggested the use of 30\% CBA without any superplasticizer and it can be used up to $50 \%$ in concrete with a superplasticizer.

Khan \& Ganesh, (2016) considered CBA as a cement replacement 10 to $30 \%$ and found that compressive strength was not increased at 28 days because the pozzolanic reaction not yet initiated at initial days. However, concrete containing $10 \% \mathrm{CBA}$ at the age 56days and onwards the compressive strength was higher than the control mix.

Argiz, et al., (Argiz et al., 2018) considered CBA (10 and 25\%) and coal fly ash (10 and 25\%) as a cement replacement with a super-plasticizer dosage (1 to $1.3 \%$ ) and declared CBA as a durable new cementitious material. They also found linear association between the chloride diffusion and chloride migration in concrete incorporated $10 \%$ of ground CBA.

Review of literature discloses that the use of CBA as sand replacement, reduces the concrete compressive strength. However, after grinded, it poses potential to be used as cementitious material, which could provide better strength performances. Therefore, this experimental study aims to assess the potentiality of CBA in concrete production. In this study the optimum proportion of CBA was selected as 10\% from the previous studies of Khan \& Ganesh, (2016); Argiz, et al., (2018); Kurama \& Kaya, (2008); Mangi, et al., (2018b). The fresh CBA was collected from a power station as shown in Fig. 2, then it was prepared according to the methodology and its performances were evaluated in terms of workability of fresh mix concrete, compressive strength and chloride permeability of hardened control mix concrete was 
compared with CBA-concrete. The strength aspects of concrete with CBA under aggressive environmental conditions may be analysis in future studies.
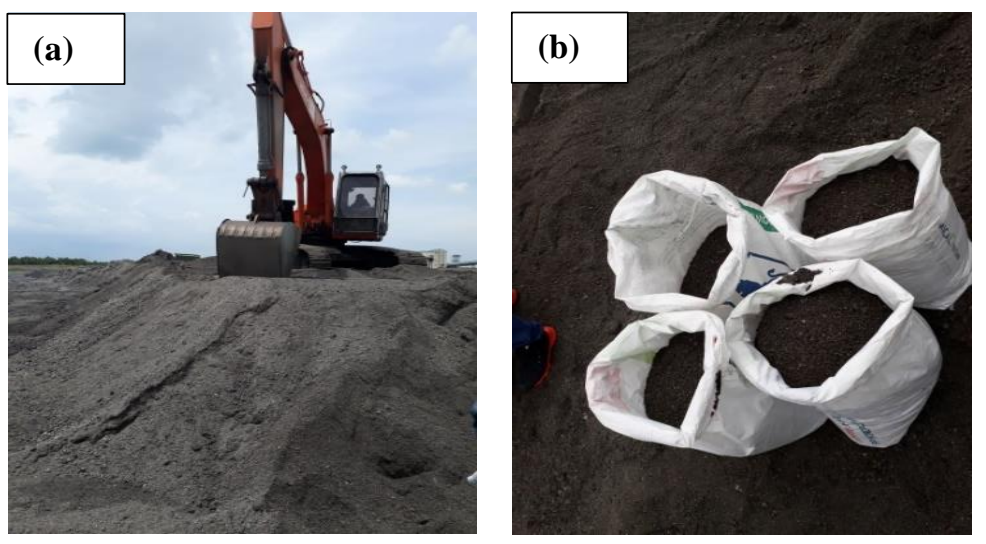

Fig. 2 - (a) Fresh bottom ash deposited at power station, (b) Collected bottom ash for the study

\section{Experimental Work}

\subsection{Materials}

Ordinary Portland Cement (OPC) was considered in this study; CBA was collected from thermal power station, situated in Selangor, Malaysia. The original CBA was dried for one day in an oven at $110 \pm 5{ }^{\circ} \mathrm{C}$, then it was proceeded for grinding in a Los Angeles apparatus for 2 hrs., then sieving through 300-micron sieve, it was further grinded in a ball mill for additional $20 \mathrm{hrs}$. The CBA was evaluated for physical properties i.e. particle size, specific surface area and specific gravity.

In addition to that ground CBA was evaluated under scanning electron microscope (SEM) analysis and image is provided in Fig. 3. It was investigated that although after graining process, CBA contains irregular, sharp, and spherical particles. Moreover, the particle size analysis for OPC and ground CBA were investigated through particle size analyzer and graphical results are demonstrated in Fig 4, which shows the particle sizes in micro-meter $(\mu \mathrm{m})$ on horizontal axis and particle finer percentile on vertical axis. It was clearly noticed that particle size distribution cure of OPC and ground CBA almost similar shape. However, it was scrutinized that $20 \mathrm{hrs}$. grinding process for CBA is feasible to get CBA particles as comparable to the OPC. Moreover, X-ray fluorescence (XRF) test was conducted to determine chemical composition of CBA and OPC. It was found to be ash of Class "F" as per ASTM C618 (2005). Comparable results have been reported by Nizar, et al., (2013), they also found that Fly ash produced through the same powerplant is classified as class "F" ash. Moreover, detailed characteristics of CBA and OPC are provided in Table 1.

Table 1 - Physical and chemical characteristics OPC and CBA

\begin{tabular}{lccc}
\hline Content (\% by weight) & OPC & CBA & ASTM C 618 Prerequisite \\
\hline $\mathrm{SiO}_{2}$ & 20.61 & 52.50 & $\mathrm{SiO}_{2}+\mathrm{Al}_{2} \mathrm{O}_{3}+\mathrm{Fe}_{2} \mathrm{O}_{3} \geq 70 \%$ \\
$\mathrm{Al}_{2} \mathrm{O}_{3}$ & 3.95 & 17.65 & \\
$\mathrm{Fe}_{2} \mathrm{O}_{3}$ & 3.46 & 8.30 & \\
$\mathrm{CaO}$ & 63.95 & 4.72 & \\
$\mathrm{TiO}_{2}$ & 0.20 & 2.17 & \\
$\mathrm{SO}_{3}$ & 3.62 & 0.84 & $\mathrm{Max} 5 \%$ \\
$\mathrm{~K}_{2} \mathrm{O}$ & - & 0.83 & \\
$\mathrm{MgO}$ & 1.93 & 0.58 & \\
$\mathrm{SrO}$ & - & 0.20 & \\
$\mathrm{P}_{2} \mathrm{O}_{5}$ & - & 0.29 & \\
$\mathrm{BaO}$ & - & 0.17 & \\
$\mathrm{ZrO}$ & - & 0.14 & \\
$\mathrm{Na}_{2} \mathrm{O}$ & - & 0.16 & \\
$\mathrm{Loss}$ on ignition $(\mathrm{LOI})$ & 2.18 & 4.01 & \\
$\mathrm{Specific} \mathrm{gravity}$ & 3.10 & 2.41 & \\
$\mathrm{Specific} \mathrm{surface} \mathrm{area}\left(\mathrm{cm}^{2} / \mathrm{g}\right)$ & 4871 & 3836 & \\
$60 \%$ particle size $(\mu \mathrm{m})$ & 21.15 & 47.78 & \\
\hline
\end{tabular}




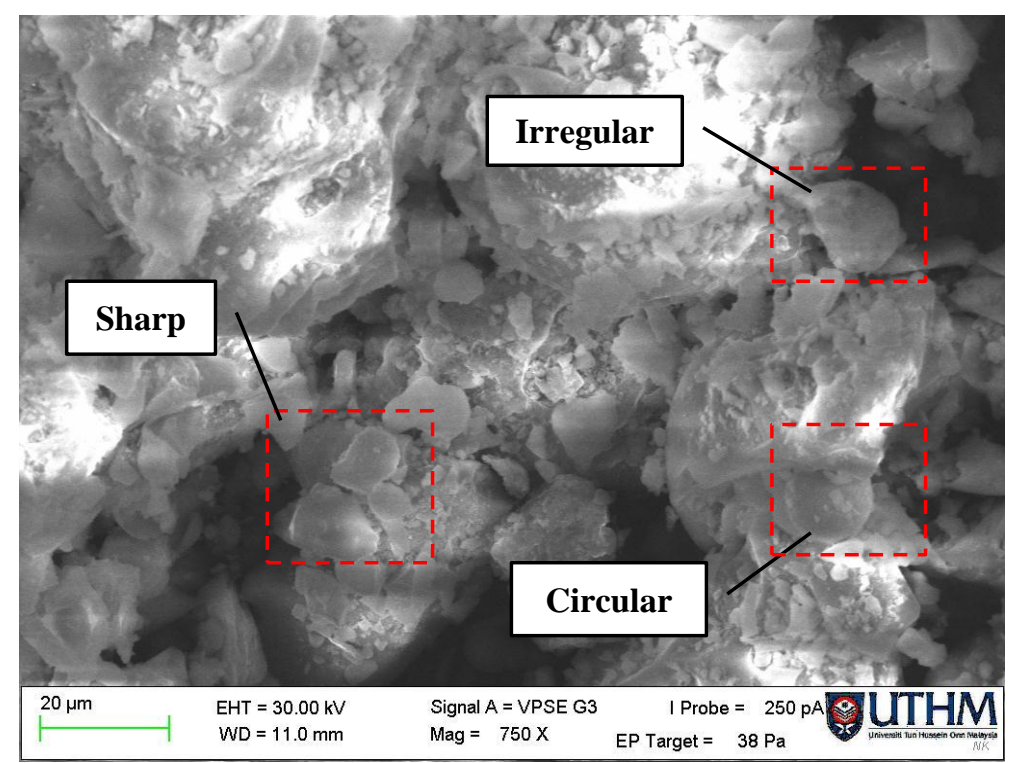

Fig. 3 - SEM image of CBA particle shapes

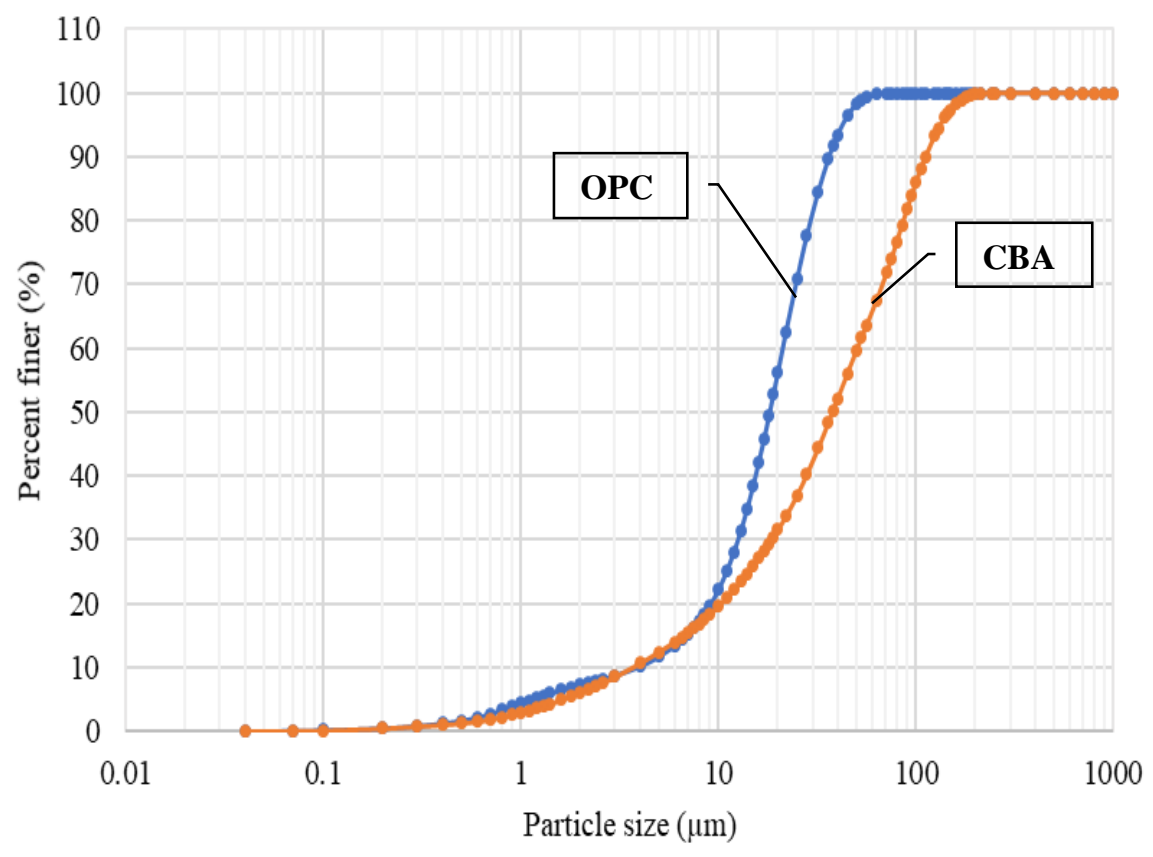

Fig. 4 - Particle size analysis of OPC and CBA

\subsection{Concrete Mixes}

Concrete mix was prepared in to two separate batches: one batch without CBA and second batch with CBA as $10 \%$ replacement of OPC by weight method. However, sand passed by $5 \mathrm{~mm}$ sieve and $10 \mathrm{~mm}$ of average size of coarse aggregates were used. Concrete mix design was prepared considering ACI method and calculated materials proportions are provided in Table 2, which shows the material required for the preparation of 1 cubic meter volume of concrete. The mixing was done mechanical drum mixer with a capacity of 75 Liters, it was operated through electric power. However, each batch of concrete was mixed for the period of 5 minutes. 
Table 2 - Concrete mix details $\left(\mathrm{kg} / \mathrm{m}^{3}\right)$

\begin{tabular}{lcc}
\hline Proportion & $\begin{array}{c}\text { Control Mix } \\
\text { (M1) }\end{array}$ & $\begin{array}{c}\text { Mix with CBA } \\
\text { (M2) }\end{array}$ \\
\hline Cement & 440 & 396 \\
CBA & - & 44 \\
Fine aggregate & 805 & 805 \\
Coarse aggregate & 828 & 828 \\
Water & 220 & 220 \\
\hline
\end{tabular}

\subsection{Casting and Curing}

Casting and curing were involved total 30 cubes of concrete having size of $100 \mathrm{~mm}$, that were prepared for the investigation of compressive strength. The demoulding were performed after 24 hours and then cubes of concrete were placed in water tank for the curing purpose up-to 90 days. Moreover, 6 cylindrical specimens (diameter $100 \mathrm{~mm}$ and length $200 \mathrm{~mm}$ ) were also cast for determination of rapid chloride penetration test; 3 of control mix and 3 containing $10 \%$ ground CBA and these specimens were cured for 28 days in water. All the curing was done at laboratory scale and tap water was stored in the PVC tanks and that was used for the purpose of curing of all type of specimens.

\subsection{Testing Procedure}

\subsubsection{Compressive Strength Test}

Compressive strength of concrete cubes were evaluated in accordance with BS EN 12390-3 (2009). After designated curing period, a set of 3 representative samples at saturated dry surface condition cubes were tested for each concrete mix for each curing regime and after the selected curing time, the samples were tested in universal load testing machine also known as compression machine with $3000 \mathrm{kN}$ loading capacity and load was applied to specimens at a rate of $7.0 \mathrm{kN}$ per second till the specimen fails. The detailed setup of compression testing machine is provided in Fig 5.

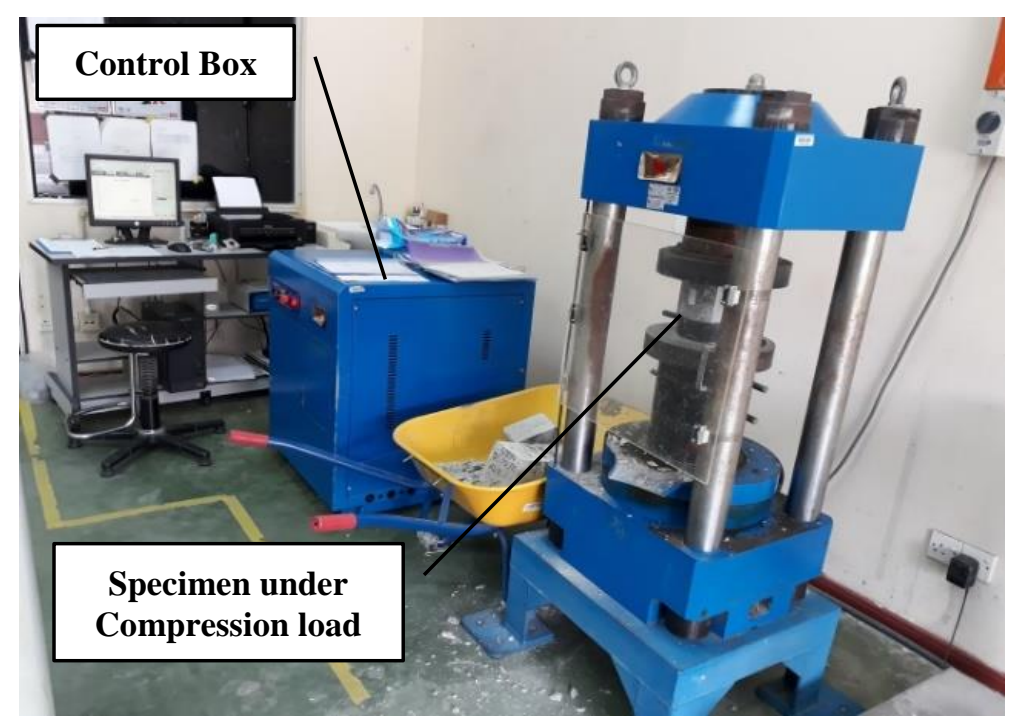

Fig. 5 - Compression testing machine

\subsubsection{Rapid Chloride Permeability Test}

The rapid chloride permeability test (RCPT) was conducted on cylindrical concrete specimens of diameter $100 \mathrm{~mm}$ and length $200 \mathrm{~mm}$, these specimens were trimmed at $50 \mathrm{~mm}$ individually. After that specimens were soaked in water for 18 hours till completely soaked and then let it surface dry in air for 1 hour. Subsequently, epoxy (silicon) were applied on both side surfaces of the samples.

However, cell contained $3.0 \% \mathrm{NaCl}$ solution from one side and other side contained $0.3 \mathrm{M} \mathrm{NaOH}$ solution. The current in ampere-seconds was recorded at 30 minutes interval throughout $6 \mathrm{~h}$. According to the charge passed through the specimens, rating of concrete permeability was assessed with reference to ASTM.C1202, (2006). Laboratory experiment set-up is provided in Fig 6, which shows the arrangement of RCPT. 


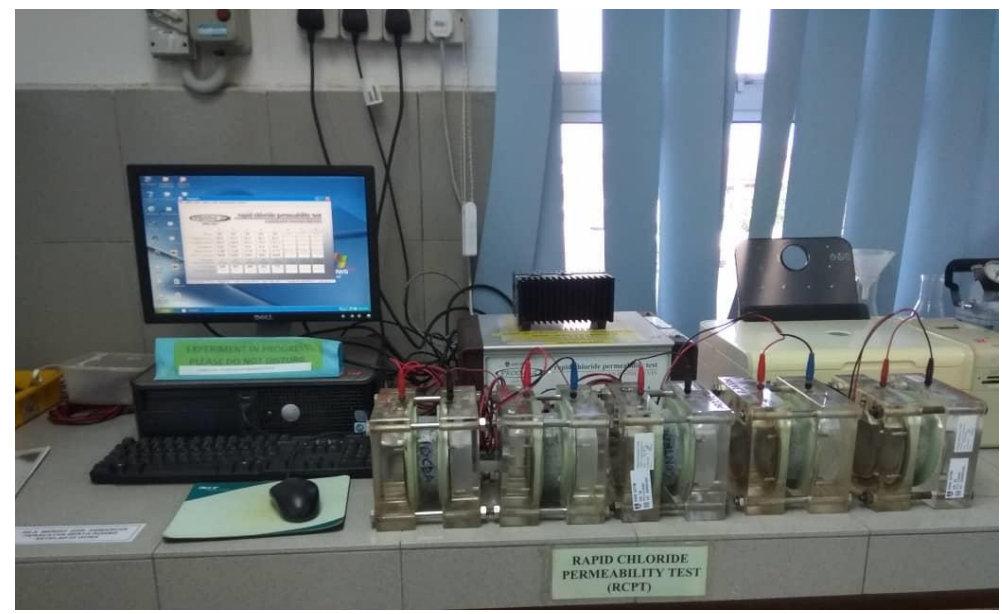

Fig. 6 - RCPT apparatus arrangements

\section{Results and Discussion}

\subsection{Slump Test}

Concrete workability was assessed through slump test referring to ASTM C143 (2015). Concrete without CBA (M1) and with $10 \%$ CBA (M2) was prepared with a fixed water to cement ratio of 050 . For the fresh M1 concrete, slump was recorded as $56 \mathrm{~mm}$, and for M2 fresh concrete it was noticed as $50 \mathrm{~mm}$, which is almost $10 \%$ lower than the M1. This performance was detected due to presence of CBA in concrete and slump reduction as to M1. shows the decreases in workability due to CBA presence, absorbed more water in the concrete mix (Wan Ibrahim et al., 2017), similar results have been reported by Khan \& Ganesh, (2016), Mangi, et al., (2018a) Mangi, et al., (2018b), Mangi, et al., (2019). It was observed that more water absorbed by CBA particles and resulting in lowering workability.

Table 3 - Workability of concrete with and without ground CBA

\begin{tabular}{lcc}
\hline Concrete Mix & Slump $(\mathbf{m m})$ & Reduction \\
\hline M1 & 56 & - \\
M2 & 50 & $10 \%$ \\
\hline
\end{tabular}

\subsection{Compressive Strength}

The compressive strength results are provided in Table 4 and Fig 7. It was observed that development of compressive strength for concrete with ground CBA (M2) is almost same as to control mix (M1). At the curing age of 7, 28 and 56 days, concrete compressive strength was reduced with the replacement of OPC by ground CBA. But, after 56 days, the strength of M2 was increased about $4.7 \%$ than M1 at 90 days. This phenomenon indicated that the pozzolanic reaction induced by ground CBA is originated after 56 days. However, Rafieizonooz et al., (2016) also reported that fly ash as replacement of cement in concrete exhibits pozzolanic activity at latter ages and pozzolanic reaction not began at early 28 days. Therefore, initial strength is due to the presence of cement. The results of fly ash concrete and concrete containing ground CBA were found to be comparable, because both are the by-products of same power plant and almost similar chemical characteristics.

Table 4 - Concrete Compressive strength performance

\begin{tabular}{lccc}
\hline Curing age (days) & $\begin{array}{c}\mathbf{M 1} \\
\left(\mathbf{N} / \mathbf{m m}^{2}\right)\end{array}$ & $\begin{array}{c}\mathbf{M 2} \\
\left(\mathbf{N} / \mathbf{m m}^{2}\right)\end{array}$ & $\begin{array}{c}\text { \% increase or } \\
\text { decrease }\end{array}$ \\
\hline 7 & $29.5_{(3.36)}$ & $29.0_{(3.32)}$ & -1.7 \\
28 & $44.5_{(3.58)}$ & $39.2_{(3.44)}$ & -11.9 \\
56 & $46.8_{(4.16)}$ & $43.5_{(4.89)}$ & -7.1 \\
90 & $50.8_{(2.35)}$ & $53.2_{(2.25)}$ & 4.7 \\
\hline
\end{tabular}

The subscript values in the table, indicated the standard deviation. 


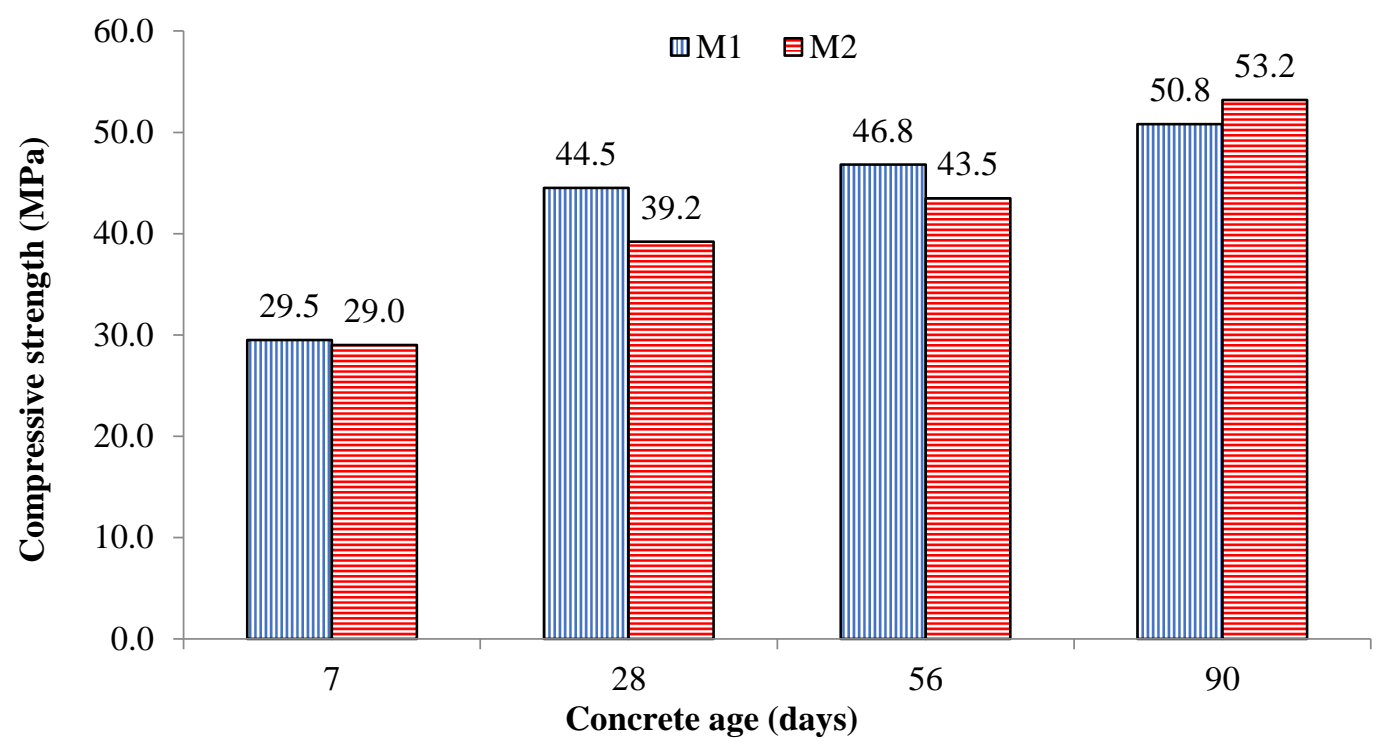

Fig. 7 - Concrete compressive strength performance at different curing periods

\subsection{Rapid Chloride Permeability Test}

The concrete specimens were evaluated for RCPT test in this study. It was performed for control specimen and for concrete holding $10 \%$ ground CBA at 28 days. Sample was evaluated on the basis of charge passed, the rating of charge passed has been given by ASTM C1202 (2006), which categorized as high $(>4,000)$, moderate $(2,000-4,000)$ and low $(1,000-2,000)$. RCPT test performance for the control mix concrete (M1) and for concrete holding $10 \%$ CBA is provided in Fig. 8. Although, compressive strength data indicated that the pozzolanic reaction does not yet initiated at 28 days, but reduction is charge was noticed in this case, which could be a result of filler effect. The fine particles of cementitious materials settled in the free pores of concrete mix and resulting in the denser concrete (Bakar, et al., 2011), which resist the penetration chloride ions in the concrete (Jaya, et al, 2011).

However, current study shows that rapid chloride penetration in the concrete with ground CBA is lower than control concrete. It has been earlier validated by Yang \& Chiang, (2005) that the concrete with w/c ratio of 0.50 were found 7890 charge passed. Although, Singh \& Siddique, (2014) considered CBA as sand replacement in concrete but it delivers better chloride penetration resistance and lower RCPT value was noticed in CBA-concrete.

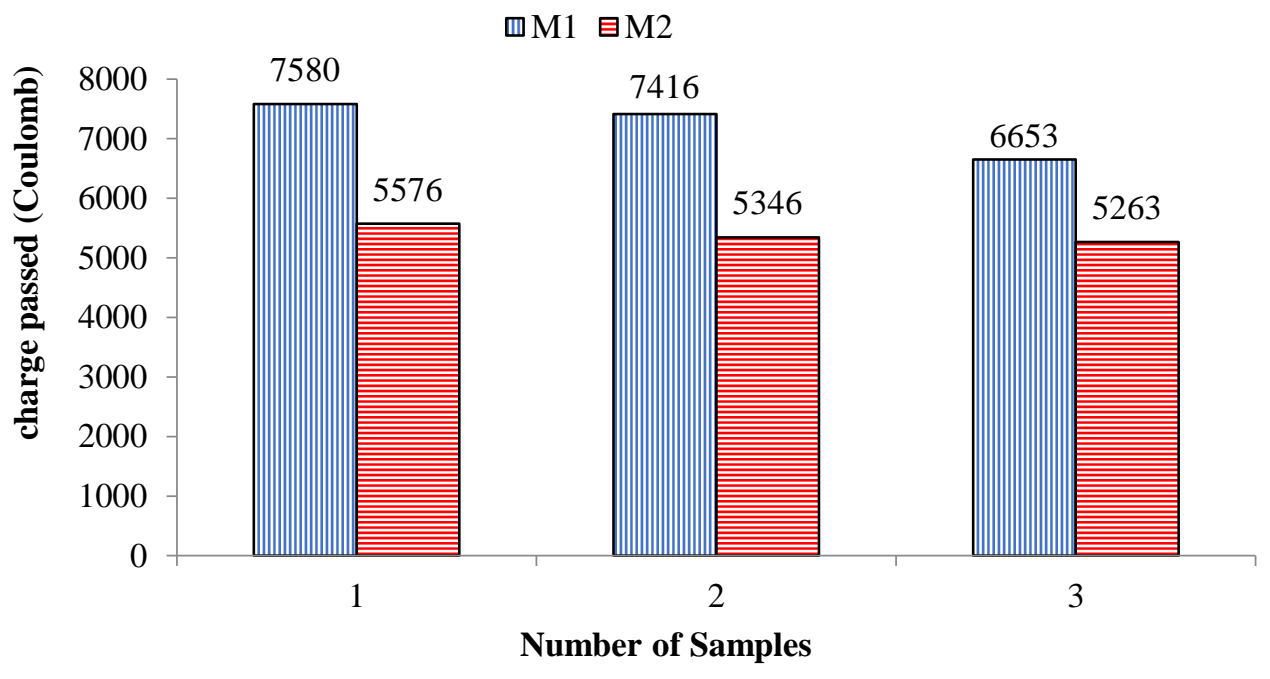

Fig. 8 - Rapid chloride penetration of concrete with and without CBA

\subsection{Compressive Strength and RCPT Relationship}

The compressive strength and RCPT relationship were prepared at 28 days as provided in Fig 9. It shows that concrete without CBA (M1) higher strength and higher charge passed through it, but concrete incorporated 10\% CBA 
gives lower strength as well as gives lower charge passed through it. Lower in the strength is the indication that pozzolanic reaction is not yet initiated at the age of 28 days (Khan \& Ganesh, 2016). Beside that presence of CBA offers good potentiality to reduce chloride penetrability through concrete, it will be more beneficial in terms of durable concrete construction.

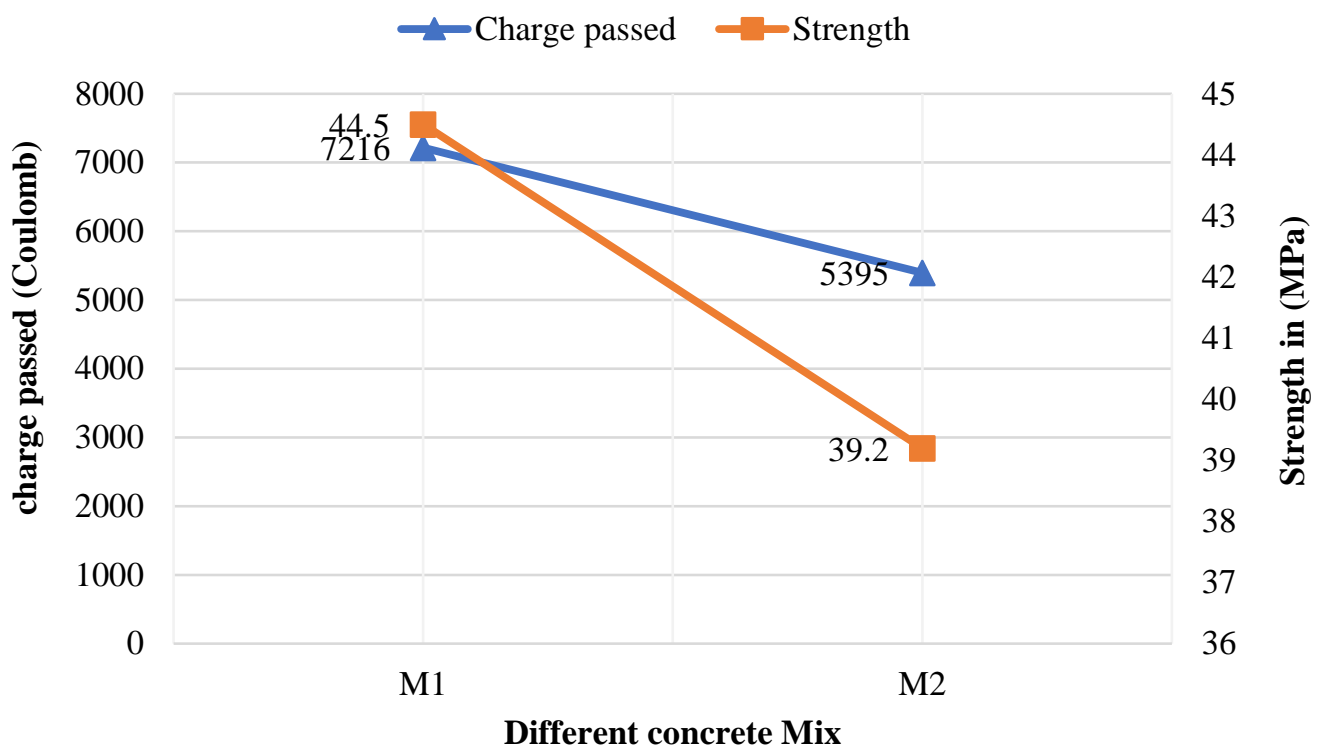

Fig. 9 - Relationship between strength and RCPT

\subsection{SEM Inspection}

The microstructure inspection was done through scanning electron microscopy (SEM) immediately after the compression test; crushed samples were further inside investigated through the advanced technique known as SEM analysis. Representative samples of concrete with and without CBA were investigated at a magnification of $1.00 \mathrm{KX}$, the images provided in Fig 10 and 11 at resolution $1.0 \mathrm{KX}$ shows that the concrete with $10 \%$ CBA and concrete without $\mathrm{CBA}$, respectively. The concrete mixture gaining its strength through the establishment of C-S-H gel with in the concrete due to cement paste. However, C-S-H formation plays important rule in the strength development, it could be seen as while highlighted solid portion in the SEM images (Mangi et al., 2018; Mangi, et al., 2019). However, formation C-S-H gel was observed in M1 and M2, but denser C-S-H were noticed in M2, which is an indication that pozzolanic reaction were takes place due to addition of CBA, which resulting in the strength development at the age of 90 days.

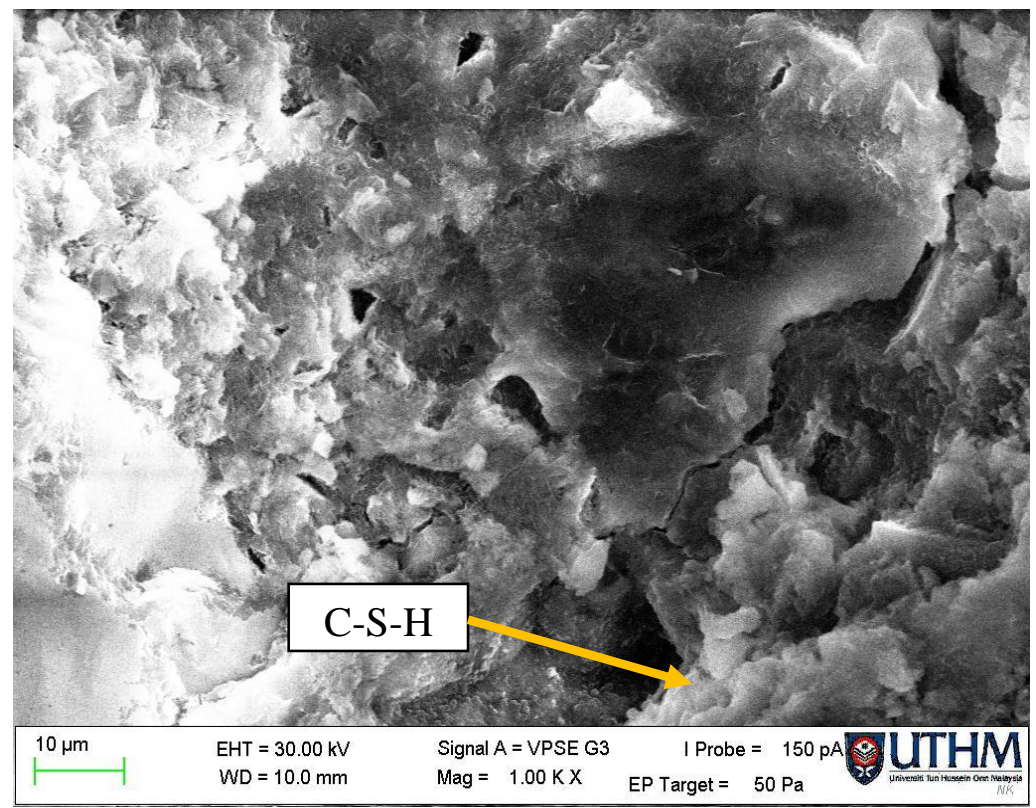

Fig. 10 - Concrete with $10 \%$ CBA (M2) 


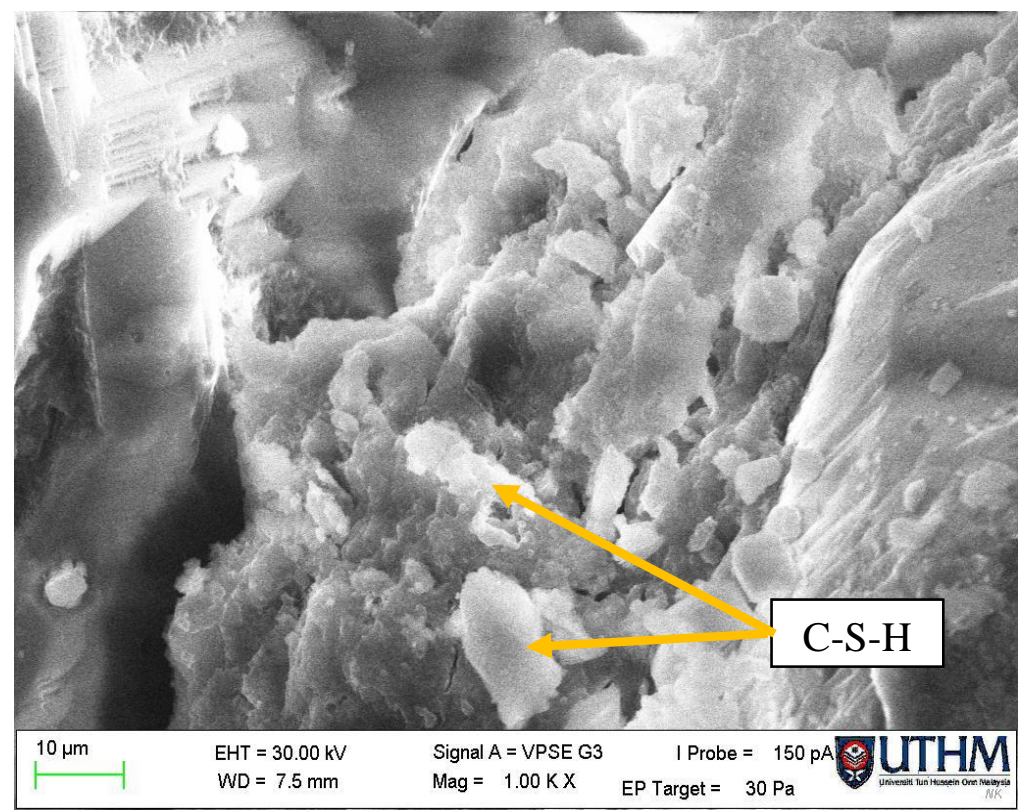

Fig. 11 - Concrete without CBA (M1)

\subsection{Financial and Environmental Benefits}

Financial analysis is the important aspect for the product feasibility and commercial viability, it involves whole manufacturing process cost. However, this study adopted 10\% of CBA as OPC. The concrete prepared with and without CBA was evaluated. There are two benefits of CBA utilization in concrete; one is cost saving and other is environmental benefit. The portion of cement that was saved by the utilization of CBA was calculated. In this study, the cost analysis based of the local rates and cost benefit was calculated as the cost of cement that saved minus cost of grinding process. However, this study involves same mix proportions of sand, coarse aggregate, and water, therefore, no need to calculate them separately. The cost is only influenced by the replacement of cement, assuming the transportation cost is the same for the OPC and CBA. The cost of one bag $(50 \mathrm{~kg})$ of OPC cement is RM. 20.00. The medium voltage off-peak period industrial tariff is taken as $0.219 \mathrm{RM} / \mathrm{kWh}(\mathrm{TNB}, 2014)$. The CBA grinded of 22 hours $(2 \mathrm{hrs}$. in Los Angeles machine $+20 \mathrm{hrs}$. in ball) with $0.75 \mathrm{HP}$ i.e. $0.75 \mathrm{kWh}$. For each period $12 \mathrm{~kg}$ of CBA was taken for the grinding. In control mix $440 \mathrm{~kg}$ cement was used to prepare $1 \mathrm{~m}^{3}$ volume of concrete, from Table 5, it can be observed that for one cubic meter of concrete, can save RM. 4.38 which shows that $10 \%$ CBA concrete is economical than control mix concrete. Moreover, carbon dioxide $\left(\mathrm{CO}_{2}\right)$ emissions also produced during cement manufacturing process. Therefore, the production $\mathrm{CO}_{2}$ emissions is directly associated with amount of cement production. Hence, it was observed that, if $10 \%$ CBA is adopted as replacement of OPC in concrete could reduce the $44 \mathrm{~kg}$ of $\mathrm{CO}_{2}$ emissions. Because mostly, 1 ton of cement emits 1 ton of $\mathrm{CO}_{2}$ (Khan \& Ganesh, 2016).

Table 5 - Cost benefit in (RM) per one cubic meter of concrete

\begin{tabular}{lcc}
\hline Description & $\begin{array}{c}\text { Concrete } \\
\text { without CBA }\end{array}$ & $\begin{array}{c}\text { Concrete with } \\
\text { 10\% CBA }\end{array}$ \\
\hline Cement used (kg) & 440 & 396 \\
Cement cost per kg (RM) & 0.40 & \\
Cost of cement (RM) & 176 & 158.40 \\
CBA (kg) & - & 44 \\
Cost of CBA (RM) & - & 13.22 \\
Total Cost per 1 m ${ }^{3}$ & 176.00 & 171.62 \\
\hline
\end{tabular}

\section{Conclusions}

Following conclusions can be made based on the experimental outcomes.

i. Chemical characteristics of CBA confirmed that it poses good pozzolanic properties.

ii. Addition of CBA in concrete decreases the workability due to more water absorption. 
iii. CBA presence in concrete reduces its compressive strength at early ages, but later ages compressive strength was found to be more than control mix. In CBA concrete about $4.7 \%$ higher strength was recorded than the control mix at the age of 90 days.

iv. Presence of fine CBA particles in concrete, make it denser and resulting in the low chloride permeability through concrete containing CBA as compared to control mix. It was declared as durable material for the construction in terms of chloride penetration.

v. It was observed that $10 \%$ incorporation of CBA as cement replacement in concrete is an economical option and it reduces the $\mathrm{CO} 2$ emissions, which means that it is also beneficial for the environmental as well.

Moreover, the use of ground CBA is found to be suitable as cementitious material in concrete, forthcoming research is required to extend this idea for the strength performance of CBA-concrete under aggressive environmental conditions.

\section{Acknowledgement}

The authors of this work are acknowledged the financial supports of Universiti Tun Hussein Onn Malaysia under the grant Tier-1 Vot No. U838.

\section{References}

ACAA. (2017). American Coal Ash Association Production and Use News Release. American Coal Ash Association, 14. Retrieved from www.acaa-usa.org

Argiz, C., Moragues, A., \& Menéndez, E. (2018). Use of ground coal bottom ash as cement constituent in concretes exposed to chloride environments. Journal of Cleaner Production, 170, 25-33

ASTM.C1202. (2006). Understanding AASHTO T277 and ASTM C1202 Rapid Chloride Permeability Test. GRACE Construction

ASTM C143/C143M. (2015). Standard Test Method for Slump of Hydraulic-Cement Concrete. Astm C143, (1), 1-4

ASTM C618-05. (2005). Standard Specification for Coal Fly Ash and Raw or Calcined Natural Pozzolan for Use. Annual Book of ASTM Standards, 3-6

Aydin, E. (2016). Novel coal bottom ash waste composites for sustainable construction. Construction and Building Materials, 124, 582-588

Bakar, B., Jaya, R., Johari, M., \& Ibrahim, M. (2011). Engineering Properties of Normal Concrete Grade 40 Containing Rice Husk Ash at Different Grinding Time. Advances in Materials Sciences, 11(1), 10-19

BS EN 12390-3 (2009). Testing Hardened Concrete, Part 3: Compressive Strength of Test Specimens. British Standards Institution

CEA. (2017). Report on Fly Ash Generation at Coal/Lignite Based Thermal Power Stations and its Utilization in the Country for the year 2016-17, (December), 1-63

Cheriaf, M., Rocha, J. C., \& Péra, J. (1999). Pozzolanic properties of pulverized coal combustion bottom ash. Cement and Concrete Research, 29(9), 1387-1391

Deonarine, A., Kolker, A., \& Doughten, M. (2015). Trace Elements in Coal Ash. U.S. Geological Survey. USGS. https://doi.org/10.1016/B978-0-408-03309-1.50002-2

Hui, K. S., Hui, K. N., Lee, S. K., \& Ash, a C. F. (2009). A Novel and Green Approach to Produce Nano- Porous Materials Zeolite A and MCM-41 from Coal Fly Ash and their Applications in Environmental Protection. International Journal of Chemical and Biological Engineering, 3, 165-175 
Jaya, R. P., Bakar, B. H. A., Johari, M. A. M., \& Ibrahim, M. H. W. (2011). Strength and permeability properties of concrete containing rice husk ash with different grinding time. Central European Journal of Engineering, 1(1), 103-112

Khairul Nizar, I., Al Bakri, A. M. M., Rafiza, A. R., Kamarudin, H., Abdullah, A., \& Yahya, Z. (2013). Study on Physical and Chemical Properties of Fly Ash from Different Area in Malaysia. Key Engineering Materials, 594-595, 985-989

Khan, R. A., \& Ganesh, A. (2016). The effect of coal bottom ash ( CBA ) on mechanical and durability characteristics of concrete. Journal of Building Materials and Structures, (3), 31-42

Kim, H.-K. (2015). Utilization of sieved and ground coal bottom ash powders as a coarse binder in high-strength mortar to improve workability. Construction and Building Materials, 91, 57-64

Kurama, H., \& Kaya, M. (2008). Usage of coal combustion bottom ash in concrete mixture. Construction and Building Materials, 22(9), 1922-1928

Mangi, S. A., Jamaluddin, N., Wan Ibrahim, M. H., Abdullah, A. H., Abdul Awal, A. S. M., Sohu, S., \& Ali, N. (2017). Utilization of sugarcane bagasse ash in concrete as partial replacement of cement. IOP Conference Series: Materials Science and Engineering, 271(1)

Mangi, S. A., Wan Ibrahim, M. H., Jamaluddin, N., Arshad, M. F., \& Putra Jaya, R. (2018). Short-term effects of sulphate and chloride on the concrete containing coal bottom ash as supplementary cementitious material. Engineering Science and Technology, an International Journal. 22(2), 515-522. https://doi.org/10.1016/j.jestch.2018.09.001

Mangi, S. A., Wan Ibrahim, M. H., Jamaluddin, N., Arshad, M. F., \& Shahidan, S. (2019). Performances of concrete containing coal bottom ash with different fineness as a supplementary cementitious material exposed to seawater. Engineering Science and Technology, an International Journal, 22(3), 929-938. https://doi.org/10.1016/j.jestch.2019.01.011

Mangi, S. A., Wan Ibrahim, M. H., Jamaluddin, N., Shahidan, S., Arshad, M. F., Memon, S. A., \& Setiawan, M. I. (2019). Influence of Ground Coal Bottom Ash on the Properties of Concrete. International Journal of Sustainable Construction Engineering and Technology, 9(2), 26-34

P. Kadam, M., \& D. Patil, Y. (2014). The Effect of sieved Coal Bottom Ash as a Sand Substitute on the Properties of Concrete with Percentage Variation in Cement. American Journal of Civil Engineering and Architecture, 2(5), 160-166

Rafieizonooz, M., Mirza, J., Salim, M. R., Hussin, M. W., \& Khankhaje, E. (2016). Investigation of coal bottom ash and fly ash in concrete as replacement for sand and cement. Construction and Building Materials, 116, 15-24

Sathonsaowaphak, A., Chindaprasirt, P., \& Pimraksa, K. (2009). Workability and strength of lignite bottom ash geopolymer mortar. Journal of Hazardous Materials, 168(1), 44-50

Singh, M., \& Siddique, R. (2014). Compressive strength, drying shrinkage and chemical resistance of concrete incorporating coal bottom ash as partial or total replacement of sand. Construction and Building Materials, 68, 39-48

Singh, M., \& Siddique, R. (2016). Effect of coal bottom ash as partial replacement of sand on workability and strength properties of concrete. Journal of Cleaner Production, 112, 620-630

Singh, M., Siddique, R., Ait-Mokhtar, K., \& Belarbi, R. (2015). Durability Properties of Concrete Made with High Volumes of Low-Calcium Coal Bottom Ash As a Replacement of Two Types of Sand. Journal of Materials in Civil Engineering, 28(2009), 04015175 
TNB. (2014). Electricity Tariff Schedule. Tenaga Nasional Berhad, (January), 1-5. Retrieved from https://www.tnb.com.my/commercial-industrial/pricing-tariffs 1

Wan Ibrahim, M. H., Mangi, S. A., Burhanudin, M. K., Ridzuan, M. B., Jamaluddin, N., Shahidan, S., Othman \& N. H. (2017). Compressive and flexural strength of concrete containing palm oil biomass clinker and polypropylene fibres. IOP Conference Series: Materials Science and Engineering, 271(1). 012011. doi:10.1088/1757-899X/271/1/012011

Yang, C. C., \& Chiang, C. T. (2005). On the relationship between pore structure and charge passed from RCPT in mineralfree cement-based materials. Materials Chemistry and Physics, 93(1), 202-207 